\title{
Silicosis: progressive massive fibrosis with eggshell calcification
}

\author{
Kamal Gera, Vikas Pilaniya, Ashok Shah
}

Department of Respiratory Medicine, Vallabhbhai Patel Chest Institute, University of Delhi, Delhi, India

\section{Correspondence to}

Professor Ashok Shah, ashokshah99@yahoo.com

Accepted 8 September 2014

\section{DESCRIPTION}

A 35-year-old man, a never smoker, had a cough and breathlessness for 1 year. He had worked as a stone crusher for 8 years. Apart from decreased breath sounds on auscultation, his physical examination was within normal limits. Pulmonary function testing was suggestive of moderately severe restriction with reduced diffusion capacity. Chest X-ray revealed diffuse reticulonodular shadows and multiple mass-like symmetrical lesions with irregular margins separated from the pleura by aerated lungs, an appearance known as 'angel's wings' ${ }^{1}$ (figure 1).
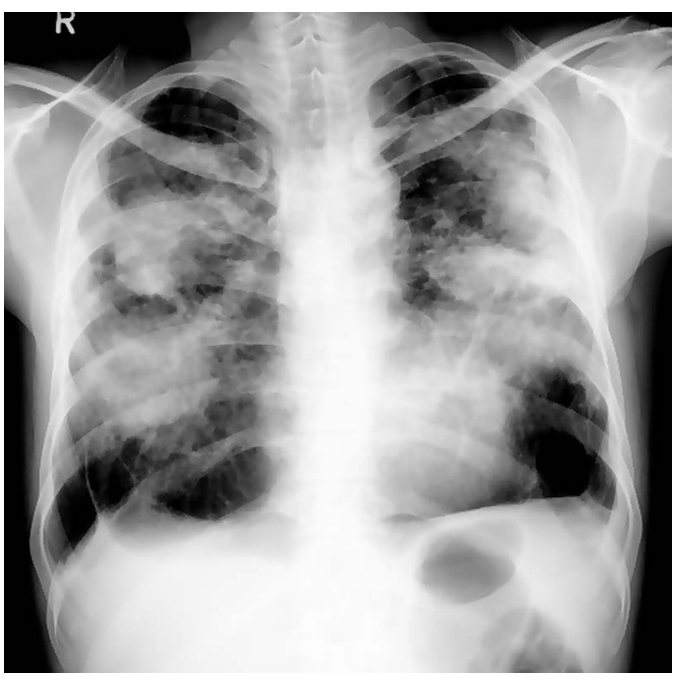

Figure 1 Chest X-ray on presentation showing reticulonodular shadows and multiple mass-like symmetrical lesions with irregular margins. This is known as 'angel's wings' appearance. The lateral interfaces of the mass lesions parallel the lateral chest wall.
CT of thorax demonstrated eggshell calcification of lymph nodes and within the masses (figure $2 \mathrm{~A}$, mediastinal window), along with large, symmetrical, bilateral, conglomerate masses having irregular margins and nodular densities (figure $2 \mathrm{~B}$, lung window). Furthermore, lateral interfaces of the mass lesions were parallel to the lateral chest wall. Imaging, supported by occupational history, was suggestive of progressive massive fibrosis (PMF) due to silicosis.

Radiologically, silicosis caused by inhalation of silica particles can be classified as simple or complicated silicosis also known as PMF, which presents with large and conglomerate opacities. These opacities, with ill-defined margins, are larger than $1 \mathrm{~cm}$, symmetrical in distribution and often with calcifications and surrounding emphysematous areas. ${ }^{2}$ The lateral interfaces of the lesions are characteristically parallel to the lateral chest wall, as seen in our patient. Patients with silicosis and coal-worker's pneumoconiosis are commonly affected with peripheral calcification of lymph nodes known as 'eggshell calcification'. ${ }^{3}$ Approximately a fourth of these patients have silicotuberculosis, ${ }^{2}$ but we were unable to find any evidence in our patient.

\section{Learning points}

- Complicated silicosis or progressive massive fibrosis is characterised by mass lesions.

- Lateral interfaces of the masses typically parallel the lateral chest wall.

- 'Eggshell calcification' or peripheral calcification is a characteristic feature of progressive massive fibrosis seen in silicosis.
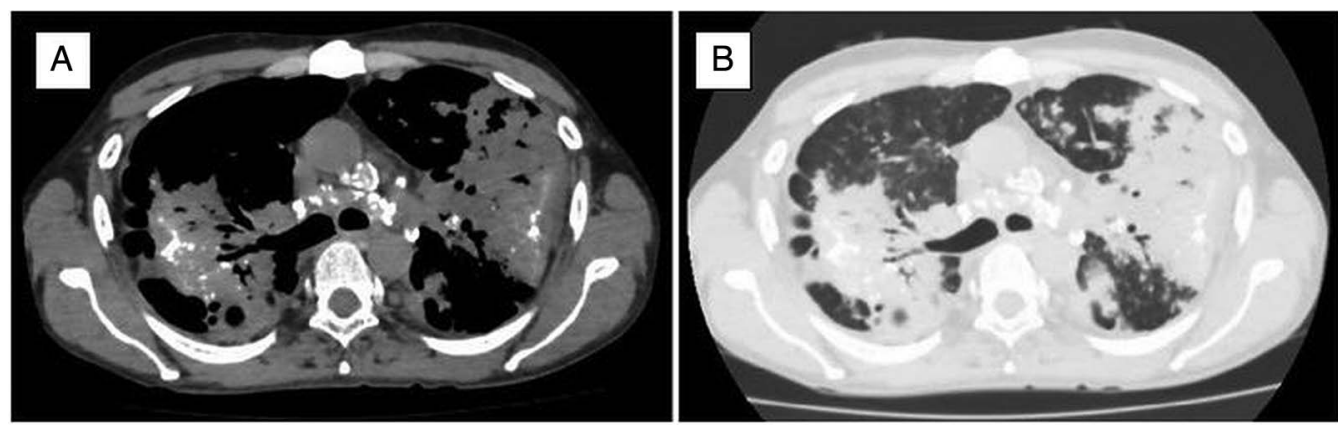

To cite: Gera K, Pilaniya V, Shah A. BMJ Case Rep Published online: [please include Day Month Year] doi:10.1136/bcr-2014206376

Figure 2 Non-contrast high-resolution CT of thorax showing (mediastinal window: A) eggshell calcification of lymph nodes and calcification within the masses; (lung window: B) large, symmetrical, bilateral conglomerate masses having irregular margins and nodular densities. The lateral interfaces of the mass lesions parallel the lateral chest wall. 
Contributors KG, VP and AS collected the clinical data and reviewed the literature. $K G, V P$ and $A S$ drafted the manuscript and were responsible for the clinical workup of the patient. AS is responsible for the genuineness of the data, the concept and is also the guarantor of the paper. All authors have read and approved the final manuscript.

Competing interests None.

Patient consent Obtained.

Provenance and peer review Not commissioned; externally peer reviewed.

\section{REFERENCES}

1 Yang JC, Liu KL. Coal workers' pneumoconiosis with progressive massive fibrosis, CMAJ 2012;184:E878.

2 Chong S, Lee KS, Chung MJ, et al. Pneumoconiosis: comparison of imaging and pathologic findings. Radiographics 2006;26:59-77.

3 Gross BH, Schneider HJ, Proto AV. Eggshell calcification of lymph nodes: an update. Am J Roentgenol 1980;135:1265-8.

Copyright 2014 BMJ Publishing Group. All rights reserved. For permission to reuse any of this content visit http://group.bmj.com/group/rights-licensing/permissions.

BMJ Case Report Fellows may re-use this article for personal use and teaching without any further permission.

Become a Fellow of BMJ Case Reports today and you can:

- Submit as many cases as you like

- Enjoy fast sympathetic peer review and rapid publication of accepted articles

- Access all the published articles

- Re-use any of the published material for personal use and teaching without further permission

For information on Institutional Fellowships contact consortiasales@bmjgroup.com

Visit casereports.bmj.com for more articles like this and to become a Fellow 